\title{
The Effects of Online Learning on Psychomotor Changes in Short Story Writing for Students of Class VII of SMPN 4 Banda Aceh
}

\author{
Erfinawati $^{1^{*}}$, Ismawirna $^{2}$, Yulsafli $^{3}$, Darmawati $^{4}$ \\ ${ }^{1,2,3,4}$ Faculty of Teacher Training and Education, Universitas Serambi Mekkah, \\ Aceh, Indonesia \\ *Corresponding Author: erfinawati@serambimekkah.ac.id
}

\begin{abstract}
The purpose of this study was to describe the effects of online learning on psychomotor changes in short story writing among students of SMPN 4, Banda Aceh. The data were taken from the students' short stories at SMPN 4 Banda Aceh. The methods used were descriptive qualitative and quantitative. Techniques used to collect the datawerea test, observation, interview and documentation. The data were then processed using the SPSS program. Based on the results of the linearity test, there was a significant linear relationship between psychomotor changes $(X)$ and learning in short story writing $(Y)$. However, this relationship was only slightly affected, namely $8.6 \%$ while the rest was influenced by external factors from the research variables, namely laziness and student boredom. The results of the regression test also show that online learning at SMPN 4 Banda Aceh has no significant effects on psychomotor changes in writing short stories. Meanwhile, the results of interviews with teachers and students revealed that online learning has positive and negative effects depending on the learning patterns.
\end{abstract}

Keywords: online learning, psychomotor, short stories writing.

\section{Introduction}

Online and offline learning systems must inevitably continue to be carried out in the midst of the COVID-19 pandemic. Online learning is one of the learning alternatives that are widely used in schools in the modern era. Online learning is done using the internet network so that students can connect directly with the teacher with the application used. This requires teachers to be more creative so that they can improve student achievement. Online learning is learning that is carried out online used during the COVID-19 pandemic. Nakayama (2007) suggests that online learning is a learning process that utilizes the internet network. Online learning also has weaknesses, namely obstacles in getting connections or networks (Mustofa, 2019). Writing short stories is not an easy thing for students to do.Here, students must be given motivation and dancing media to respond to learning to write short stories. According to Ghirardini (in Kartika, 2018) "Online provides effective learning methods, such as practicing with related feedback, combining collaborative activities with independent learning, personalizing learning based on student needs and using simulations and games". Meanwhile, according to Permendikbud No. $109 / 2013$ distance education is a teaching and learning process carried out remotely through the use of various communication media. Gunawan (2020) argues that online learning is "an activity that can be done from home and can be done anytime so that it does not cause problems because learning is not bound by time.

Online learning requires students to complete assignments so as to give changes to students' psychomotor. This change involves changes in students' writing skills. Student boredom has an impact on psychomotor changes so that students' writing is often unclear. Psychomotor is a domain related to skill learning outcomes (psychomotor) can be measured through: (1) direct observation and assessment of student behavior during the practical learning process, (2) after following learning, namely by giving tests to students to measure knowledge, skills, and attitudes, (3) some time after learning is complete and later in the work environment.The low 
short story writing skills of students are caused by a lack of motivation to participate in short story writing lessons and the low enthusiasm of students in writing. In addition, students still feel compelled to write. Students also often find it difficult to start a story, and students cannot develop an outline into a story. the story is complete and good and coherent.

The difficulty of students in writing short stories deserves good attention from teachers and parents. Not to mention that this learning must be done online. The use of the right media will motivate students in the process of writing short stories. Writing is a combination of process and product. The process, namely when collecting ideas so as to create writing that can be read by the reader (product) refers to the implementation process. Through writing activities, a person can communicate indirectly. Ak Gift (2010) says, "Writing is an activity of delivering messages by using language as the medium". Tarigan (1994) says, "Writing is lowering or painting graphic symbols that describe a language that can be understood by someone so that other people can read and understand the graphic symbols".

\section{Methods}

The quantitative and qualitative descriptive methods were used in this to describe the data based on facts objectively according to the data found in the form of words and numbers. This study aimed to examine the effects of online learning on the students' psychomotor changes in short story writing at SMPN 4 Banda Aceh. In this study, there were two variables observed, namely psychomotor changes as an independent variable and writing short stories in online learning as the dependent variable. The data were in the form of short stories composed by students of SMPN 4 Banda Aceh, totaling 40 stories. The techniques used to collect data in this study were a test and non-test.

\section{Results and Discussions}

This study aims to determine the effects of online learning in writing short stories for Banda Aceh students. Data analysis was performed using multiple regression analysis using the SPSS (Statistical Product and Service Solutions) 22.0 for Windows Evolution Version program.

The following are the results of research conducted at SMPN Banda Aceh using the SPSS (Statistical Product and Service Solutions) 22.0 for Windows Evolution Version program.

Table 1

Description of Research Variables at SMPN 4 Banda Aceh

\begin{tabular}{llccccc}
\hline School & Variable & N & Minimum & Maximum & Mean & $\begin{array}{c}\text { Std. } \\
\text { Deviation }\end{array}$ \\
\hline SMPN 4 & Psychomotor & 40 & 75 & 95 & 83,75 & 5,032 \\
& $\begin{array}{l}\text { Writing Short } \\
\text { Stories Online }\end{array}$ & 40 & 70,8 & 91,7 & 80,93 & 5,1594 \\
\hline
\end{tabular}

Based on Table 1 above, it can be seen that the maximum score of psychomotor changes for students of SMPN 4 Banda Aceh in online learning is the highest at 95 and the lowest at 75. From the average score, it is known that the value of writing short stories is in the good category. This value includes not experiencing a decrease or increase from the average score of students in writing short stories face to face which is in the good category. However, this is a consideration for teachers to continue to improve learning to write short stories online so that they are in the good category.

"The Importance of Digital Media for Sustainable Learning, Research, and Community Service during The COVID-19 Pandemic" 
Based on the description of the data, it can be concluded that there is no significant change in online learning at SMPN 4 Banda Aceh. This happens because the school provides a special teacher in learning to write short stories, namely every Saturday. Students are familiar with writing short stories. Learning to write short stories is also given at the beginning of learning so that students do not feel bored, bored and lazy. The media provided in motivating students is very good in expressing their ideas so that students' scores in writing remain good.

1) Normality Test (Residual)

Testing the normality assumption to test the data of the independent variable (X) and the dependent variable (Y) in the resulting regression equation, is it normally distributed (H0: Data is normally distributed) and is not normally distributed (H1: Data is not normally distributed). If the data distribution is normal, then the data analysis and hypothesis testing are used parametric statistics. Testing the normality of the data using the KolmogorovSmirnovone test sample test with test criteria: if the probability is significant $>0.05$ then the data is normally distributed. Data processing in this study obtained results as shown in the following table.

Table 2

Online Learning Normality Test at SMPN 4 Banda Aceh

\begin{tabular}{ccccc}
\hline School & Variable & Statistic & Sig & conclusion \\
\hline $\begin{array}{c}\text { SMPN 4 Banda } \\
\text { Aceh }\end{array}$ & $(\mathrm{X})$ and $(\mathrm{Y})$ & 4,8117 &, $112^{\mathrm{c}}$ & foccepted $_{0}$ acced \\
\hline
\end{tabular}

The table above shows the significant value of the online psychomotor change variables (X) and online short story writing (Y). The results of the normality test at SMPN 4 Banda Aceh showed that the significant value of the study was 0.112 . This means that the value is greater than the value of (0.05). Based on these results, it can be concluded that all data are normally distributed (H0: accepted).

2) Linearity Test Results (F Test))

Testing the effect of online learning on online learning and psychomotor changes in writing short stories for Banda Aceh students. Based on the hypothesis test that has been carried out using the SPSS (Statistical Product and Service Solution) 22.0 for Windows Evolution Version program, the results of the regression of the effect of each independent variable on the dependent variable in detail can be seen in the following table.

Table 3

Online Linearity Test at SMPN Banda Aceh

\begin{tabular}{ccccccc}
\hline School & Model & $\begin{array}{c}\text { Sum of } \\
\text { Squares }\end{array}$ & Df & Mean & F & sig \\
\hline $\begin{array}{c}\text { SMPN 4 } \\
\text { Banda Aceh }\end{array}$ & Regression & 88,875 & 1 & 88,875 & 3,558 &, $067^{\text {b }}$ \\
& Residual & 949,276 & 38 & 24,981 & & \\
& Total & 1038,151 & 39 & & & \\
\hline
\end{tabular}


a. Dependent Variable: Writing Short Stories Online,

b. Predictors: (Constant): Psychomotor Changes

Based on the table above, it can be seen that the significant value of SMPN 4 Banda Aceh is 0.067 which is greater than 0.05 . Hence, it can be concluded that there is a significant linear relationship between psychomotor changes $(\mathrm{X})$ and learning to write short stories $(\mathrm{Y})$.

If we look at the F-count value of SMPN 4 Banda Aceh of 3.558 or this value is smaller than the F-table value (4.098), it can be concluded that there is a significant linear relationship between psychomotor changes (X) and learning to write short stories (Y).

3) Linear Regression Test Results (T Test)

Simple linear regression analysis is a regression method that can be used as a statistical inference tool to determine the effect of an independent variable on the dependent variable. In this study, the independent variable is psychomotor change $(\mathrm{X})$ and the dependent variable is writing short stories (Y) in online learning.

Table 4

Linear Regression Test at SMPN Banda Aceh Online

\begin{tabular}{|c|c|c|c|c|c|c|}
\hline \multirow[t]{2}{*}{ School } & \multirow[t]{2}{*}{ Model } & \multicolumn{2}{|c|}{$\begin{array}{l}\text { Unstandardized } \\
\text { Coefficients }\end{array}$} & $\begin{array}{l}\text { Standardized } \\
\text { Coefficients }\end{array}$ & \multirow{2}{*}{$\mathrm{t}$} & \multirow{2}{*}{ Sig. } \\
\hline & & B & $\begin{array}{l}\text { Std. } \\
\text { Error }\end{array}$ & Beta & & \\
\hline \multirow[t]{2}{*}{ MPN 4} & 1 (Constant) & 55,810 & 13,344 & & 4,182 &, 000 \\
\hline & Psychomotor & ,300 & ,159 & 293, & 1,886 & 067 \\
\hline
\end{tabular}

a. Dependent Variable: Writing Short Stories Online

Based on table 4, the sign value of SMPN 4 Banda Aceh is greater than 0.05, which is 0.067 , so it can be concluded that online learning has no significant effect on psychomotor changes in writing short stories. This happens because students are used to writing short stories and at school when face-to-face they provide short story writing classes.

When reviewed based on the $\mathrm{T}$ value, it shows that the T-count value is 1.886 or the value is smaller than the T-table value (2.021) and online learning has no significant effect on psychomotor changes in writing short stories

\section{Conclusion}

Based on the test, it can be concluded that online learning in writing short stories for class VII students at SMPN 4 Banda Aceh has no significant effects on psychomotor changes. In the sense that this influence has a positive and negative impact depending on the learning patterns. This happened because students were used to writing. Learning to write short stories was also given at the beginning of the lesson so that students did not feel tired of writing. 


\section{References}

Akhadiah. (2010). Jurnalistik Indonesia, Menulis Berita dan Feature, Panduan Praktis Jurnalis Profesional. Bandung: Remaja Rosdakarya

Gunawan, N. M., \&Yeni, S. F. (2020). Variations of Models and Learning Platforms for Prospective Teachers During the COVID-19 Pandemic Period. Indonesian Journal of Teacher Education, 1(2): 61-70.

Harapani, A. (2021). "Pengaruh Kuliah Daring Saat Pandemi Covid-19 Terhadap Kemampuan Mahasiswa." Psy Ar Xiv. January 5. doi:10.31234/osf.io/t4x29

Kartika, A. R. (2018). Model Pembelajaran Daring. Journal of Early Childhood Care \& Education, 2(2).

Nancy, K. P. (2020). Variasi dalam pembelajaran sebagai upaya menstimulus keterlibatan siswa dalam pembelajaran daring kelas $x$. Bachelor Thesis: Universitas Pelita Harapan.

Mustofa, M. I., Chodzirin, M., Sayekti, L., \&Fauzan, R. (2019). Formulasi Model Perkuliahan Daring Sebagai Upaya Menekan Disparitas Kualitas Perguruan Tinggi. Walisongo Journal of Information Technology, 1(2), 151.

Ansari, M. (2012). Menulis Cerpen Dengan Model Pembelajaran Learning Community pada Siswa Kelas X SMA.Jurnal Edukasi Kultura. 1 (2): 44-51.

Nakayama, M, Yamamoto H, \& S. R. (2007). The Impact of Learner Characteristics on Learning Performance in Hybrid Courses among Japanese Students. Elektronic Journal ELearning,5(3).

Permendikbud. (2013). Peraturan menteri pendidikan dan Kebudayaan Nomor 109 Tahun 2013 tentang Pembelajaran Jarak Jauh (PJJ).

Setyaningsih, S. (2010). Peningkatan Keterampilan Menulis Cerpen Mahasiswa Jurusan Bahasa Dan Sastra Indonesia Dengan Model Sinektiks yang Dikembangkan. Journal. unnes. 2(2)

Tarigan, H. G. (1994). Menulis Sebagai Suatu Keterampilan Berbahasa. Bandung: Angkasa 